\title{
Regulation of acp1, encoding a non-aspartyl acid protease expressed during pathogenesis of Sclerotinia sclerotiorum
}

\author{
Nathalie Poussereau, Sandrine Creton, † Geneviève Billon-Grand, \\ Christine Rascle and Michel Fevre
}

Laboratoire de Biologie Cellulaire Fongique (bât 405), ERS CNRS 2009, Microbiologie et Génétique, Université Claude Bernard-Lyon I, 43 Bd du 11 Novembre 1918 69622 Villeurbanne cedex, France
Author for correspondence: Michel Fevre. Tel: +33 472448378 . Fax: +33472431181. e-mail:mfevre@biomserv.univ-lyon1.fr

\begin{abstract}
When grown in the presence of sunflower cell walls, Sclerotinia sclerotiorum, an ubiquitous necrotrophic fungus, secretes several acid proteases including a non-aspartyl protease. The gene acp 1, encoding an acid protease, has been cloned and sequenced. The intronless ORF encodes a preproprotein of 252 aa and a mature protein of 200 residues. In vitro expression of acp 1 is subject to several transcriptional regulatory mechanisms. Expression induced by plant cell-wall proteins is controlled by both carbon and nitrogen catabolite repression. Glucose on its own represses acp 1 expression while ammonium repression requires the simultaneous presence of a carbon source. Ambient pH higher than pH 5 overrides induction resulting in full repression of acp1. These transcriptional regulatory mechanisms and the presence of several motifs in the promoter of acp 1 that may encode binding sites for the regulators CREA, AREA and PacC suggest the involvement of these regulators in the control of acp 1 expression. acp 1 is expressed in planta during sunflower cotyledon infection. Expression is low at the beginning of infection but increases suddenly at the stage of necrosis spreading. Comparison of in vitro and in planta acp 1 expression suggests that glucose and nitrogen starvation together with acidification can be considered as key factors controlling Scl. sclerotiorum gene expression during pathogenesis.
\end{abstract}

Keywords: acid protease, gene expression, $\mathrm{pH}$ regulation, carbon and nitrogen repression, plant pathogenesis

\section{INTRODUCTION}

During interaction of a plant parasitic fungus with its host, the pathogen secretes extracellular enzymes which can degrade the host cell-wall components. These enzymes not only contribute to generate an important assimilable nutrient source but also facilitate penetration, colonization and maceration of the host tissues. Biochemical analysis of the infection process revealed that pathogenic fungi produce a wide range of cell-walldegrading enzymes able to attack all the cell-wall polymers i.e. carbohydrates and proteins. These enzymes include cellulases, pectinases, xylanases, a range of oligosaccharide-degrading enzymes and proteases (for reviews see Oliver \& Osbourn, 1995; Annis \&

†Present address: Département de Biochimie Médicale, Centre Médical Universitaire, 1 rue Michel Servet -1211 Genève 4, Switzerland.
Goodwin, 1997; Walton, 1994). Among the cell-wall degrading enzymes produced by phytopathogenic fungi, pectinolytic enzymes have been well studied as they are typically produced in large amounts and are able to macerate plant tissues (Alghisi \& Favaron, 1995). Conversely, other enzymes such as proteases have received limited attention. However, based on the cellwall structure and on the fact that up to $10 \%$ of the plant cell wall consists of proteins (Carpita \& Gibeaut, 1993), proteolytic enzymes probably play an important role in pathogenesis. Fungal proteases would facilitate localized penetration of the pathogen by breaking down the structural fibrous glycoproteins of the plant cell wall (Rauscher et al., 1995). They could also provide nitrogenous nutrients to the fungus during infection.

The possible roles of fungal proteases in plant pathogenicity have only been investigated in a few systems and contradictory results have been obtained. An 
aspartyl protease has been identified as an important virulence factor in infections by Botrytis cinerea and as one of the factors required for establishing fungal growth within the host (Mohavedi \& Heale, 1990). In Pyrenopeziza brassicae, evidence that a cysteine protease may represent a pathogenicity determinant has been presented by complementation of a protease-negative, non-pathogenic mutant to obtain a fully pathogenic protease-positive transformant (Ball et al., 1991). In contrast, disruption of two alkaline protease encoding genes in Cochliobolus carbonum reduced the proteolytic activity without affecting virulence of the mutants. This indicates that these two enzymes are not required for pathogenicity of C. carbonum (Murphy \& Walton, 1996). The importance of proteases in pathogenicity is also suggested by the fact that plants have evolved mechanisms to counter pathogen-secreted enzymes by producing protease inhibitors (for review, see Ryan, 1990). These inhibitors may act as regulators of endogenous enzymes. They could also contribute to plant defence and host resistance by inhibiting fungal proteases and by exhibiting a strong antifungal activity (Pernas et al., 1999; Chen et al., 1999).

Extracellular proteases are produced by many pathogenic fungi but the profiles of proteases these organisms produce have often not been thoroughly investigated. It has been proposed that the range of proteases produced by a fungus reflects the adaptation of saprophytic or pathogenic fungi to the requirements of their ecological niches (St Leger et al., 1997; Bidochka et al., 1999a, b). One can imagine that in response to environmental signals, protease production during pathogenesis must be regulated by the structural cell-wall proteins, nitrogen and/or nutrient limitation, and the ambient $\mathrm{pH}$.

Sclerotinia sclerotiorum is an ubiquitous necrotrophic fungus that is able to infect a wide range of cultivated plants resulting in important economic losses. Extracellular proteins secreted by this fungus are able to degrade host cell-wall components and to macerate the plant tissues. They contain the glycoside hydrolase activities that complement polysaccharidase enzymes to release monomers from each plant cell-wall polymer (Riou et al., 1991). Each enzymic system contains several endo- and exo- enzymes and, like the pectinolytic system, must be encoded by a multigene family (Martel et al., 1996; Fraissinet-Tachet et al., 1995). With respect to their potential contribution to cell-wall degradation and matrix-protein hydrolysis, characterization of proteases and isolation of all the genes for a given enzyme are of importance in order to test the role of proteases in plant pathogenicity. During saprophytic growth and pathogenesis, Scl. sclerotiorum secretes large amounts of oxalic acid which accumulates in infected tissues and decreases rapidly the ambient $\mathrm{pH}$ (Magro et al., 1984). As ambient $\mathrm{pH}$ regulates gene expression (Caddick et al., 1986; Tilburn et al., 1995), we have focused our attention on acid proteases and we describe here the characterization and regulation of acp1, a gene that encodes a non-aspartyl acid protease expressed during the infection process.

\section{METHODS}

Biological material and culture conditions. Sclerotinia sclerotiorum S5 was maintained on potato-dextrose agar. It was grown in minimal liquid medium containing (per litre) $1 \mathrm{~g}$ $\mathrm{KH}_{2} \mathrm{PO}_{4}, 0.1 \mathrm{~g} \mathrm{MgSO}$, $0.05 \mathrm{mg}$ biotin, $250 \mathrm{mg}$ citric acid, $250 \mathrm{mg} \mathrm{ZnSO}, 50 \mathrm{mg} \mathrm{Fe}\left(\mathrm{SO}_{4}\right)_{2}, 15 \mathrm{mg} \mathrm{Cu}\left(\mathrm{SO}_{4}\right)_{2}, 25 \mathrm{mg}$ each of $\mathrm{MnSO}_{4}, \mathrm{H}_{3} \mathrm{BO}_{3}, \mathrm{NaMoO}_{4}$, and supplemented with $1 \%$ sunflower extract, or $2 \%$ glucose and $100 \mathrm{mM} \mathrm{NH}_{4} \mathrm{Cl}$. Sunflower extracts were prepared from cotyledons of 1-weekold germlings. Cotyledonary leaves were cut into very small pieces and were frozen until use. The culture medium was buffered at different $\mathrm{pH}$ values in $0.15 \mathrm{M}$ citrate/phosphate (MacIlvaine) buffer. The cultures were inoculated with mycelial disks cut from 4-d-old colonies and incubated at $24^{\circ} \mathrm{C}$ under constant agitation.

Escherichia coli strain Sure R (Stratagene) was the host for recombinant plasmids and was grown in LB broth medium supplemented with ampicillin $\left(50 \mu \mathrm{g} \mathrm{ml}^{-1}\right)$. E. coli $\mathrm{P} 2392$ was used for bacteriophage lambda EMBL3 screening and was grown in NZY medium (Sambrook et al., 1989). The plasmid pUC18 was used for cloning experiments.

Pathogenicity tests. Phytopathogenicity assays were performed on sunflower cotyledons as hosts. Sunflower seeds were sown in a peat/pouzzolane mix. Germlings were grown at $25{ }^{\circ} \mathrm{C}$ (95\% humidity) with a $14 \mathrm{~h}$ light period per day. Cotyledonary leaves from 1-week-old germlings were infected by depositing a $4 \mathrm{~mm}$ mycelial disk on the upper face of the cotyledons. At various times after inoculation (corresponding to different stages of disease development), infected cotyledons were harvested and frozen at $-80^{\circ} \mathrm{C}$. Each assay was carried out three times on separate plants. Controls were performed using mycelial disks previously heated for $30 \mathrm{~min}$ at $65^{\circ} \mathrm{C}$. All experiments were performed twice and the same pattern of symptom development was found.

Acid protease assays. The culture medium $(200 \mathrm{ml})$ was filtered to eliminate the mycelia, dialysed against distilled water then freeze-dried. Thirty infected sunflower cotyledons, collected at different stages of symptom development, were ground in a mortar and pestle in cold Tris $/ \mathrm{HCl}(0.05 \mathrm{M})$, $\mathrm{pH} 7 \cdot 5$. After $10 \mathrm{~min}$ centrifugation at $10000 \mathrm{~g}$, supernatants were collected, dialysed against distilled water then freezedried. Lyophilized proteins (i.e. proteins secreted in the culture medium or extracted from infected cotyledons) were dissolved in $3 \mathrm{ml}$ water and assayed for protease activity according to Griffen et al. (1997). ACP1 was assayed in a reaction mixture containing $200 \mu \mathrm{l}$ enzyme solution, $900 \mu \mathrm{l} 100 \mathrm{mM} \mathrm{KCl} / \mathrm{HCl}$ buffer, $\mathrm{pH} 2$, and $100 \mu \mathrm{l} 15 \%$ (w/v) azocasein dissolved in the buffer. The following buffers were used to determine the $\mathrm{pH}$ profile of the secreted proteases: $100 \mathrm{mM} \mathrm{KCl} / \mathrm{HCl}$ $(\mathrm{pH} 1.5-2.5) ; 100 \mathrm{mM}$ citrate/phosphate $(\mathrm{pH} \mathrm{2.5-7.5)}$; and $100 \mathrm{mM}$ Tris/ $\mathrm{HCl}(\mathrm{pH} 7 \cdot 5-9)$. Following a $2 \mathrm{~h}$ incubation at $37^{\circ} \mathrm{C}$, the reaction was stopped by the addition of $300 \mu \mathrm{l} \mathrm{30 \%}$ $(\mathrm{w} / \mathrm{v})$ TCA. After centrifugation of the assay mixtures for $7 \mathrm{~min}$ at $13000 \mathrm{~g}, 500 \mu \mathrm{l}$ supernatant was withdrawn and the colour reaction was developed by the addition of $500 \mu \mathrm{l} 1 \mathrm{M}$ $\mathrm{NaOH}$ and measured at $450 \mathrm{~nm}$. Appropriate controls without either enzyme or substrate were run simultaneously. One arbitrary unit of protease activity was defined as the amount of enzyme necessary to develop an absorbance of $0 \cdot 5$. Protein determinations were carried out by the method of Bradford (1976). Specific active-site inhibitors were incubated with the enzymes for $30 \mathrm{~min}$ prior to assaying the protease activity. The final concentrations for protease inhibitors (Sigma) used were $0.04 \mathrm{mM} \mathrm{E}-64$ (a cysteine protease inhibitor), $0.08 \mathrm{mM}$ PMSF (a serine protease inhibitor), 0.04 $\mathrm{mM}$ phosphoramidon 
(a metalloprotease inhibitor) and $0.04 \mathrm{mM}$ pepstatin A (an aspartyl protease inhibitor). All protease assays were run in triplicate and data are shown as mean and standard deviations. The results of one representative experiment are presented.

DNA isolation and Southern blot analysis. DNA was prepared as described by Brownlee et al. (1988) from freeze-dried mycelium grown on potato-dextrose agar. DNA was digested to completion, electrophoresed on a $0.8 \%$ agarose gel and blotted onto Nytran membranes (Schleicher and Schuell). Membranes were hybridized $(50 \%, \mathrm{w} / \mathrm{v}$, formamide, $5 \times$ SSC, $0 \cdot 2 \%, \mathrm{w} / \mathrm{v}$, SDS, $1 \times$ Denhardt's solution, $100 \mu \mathrm{g}$ denatured salmon sperm DNA ml-1) at $42{ }^{\circ} \mathrm{C}$ with a ${ }^{32} \mathrm{P}$ labelled PCR fragment or acp1 coding region. The probes were radiolabelled using a random-primed DNA labelling kit (Promega). Following overnight hybridization, membranes were washed with $2 \times$ SSC, $0 \cdot 1 \%(\mathrm{w} / \mathrm{v})$ SDS then with $0 \cdot 2 \times$ SSC, $0 \cdot 1 \%(\mathrm{w} / \mathrm{v})$ SDS.

RNA isolation and Northern analysis. Total RNA was isolated from freeze-dried mycelium or infected cotyledons after lysis in a buffer containing $50 \%(\mathrm{w} / \mathrm{v})$ guanidinium thiocyanate, followed by centrifugation in caesium chloride solutions (Sambrook et al., 1989). For Northern blotting, 15 or $30 \mu \mathrm{g}$ total RNA was loaded per lane onto $1.5 \%(\mathrm{w} / \mathrm{v})$ formaldehyde agarose gels, transferred to Nytran membranes after electrophoresis and UV cross-linked. Hybridization and washing of the membranes were done as described above. The membranes were stripped between hybridizations with different probes by washing in $5 \mathrm{mM}$ Tris/HCl, $\mathrm{pH} 8 \cdot 0,0 \cdot 2 \mathrm{mM}$ EDTA, $\mathrm{pH} 8 \cdot 5$, $0.05 \%(\mathrm{w} / \mathrm{v})$ pyrophosphate, $0.1 \times$ Denhardt's solution for $1 \mathrm{~h}$ at $65^{\circ} \mathrm{C}$ (Sambrook et al., 1989).

Preparation of a probe by PCR. For amplification of an acp1specific fragment, $\mathrm{Scl}$. sclerotiorum genomic DNA was used as the template in a PCR reaction with two degenerate oligonucleotide primers. They were respectively a $16-$ mer and a $14-$ mer of 8- and 96-fold degeneracy and were synthesized as follows: primer mixture A, 5'-TGGTAYGARTGGTAYC-3'; primer mixture $\mathrm{B}, 5^{\prime}$-ATVMAYTCNGCRTT-3' where $\mathrm{N}$ is $\mathrm{A} / \mathrm{C} / \mathrm{G} / \mathrm{T}, \mathrm{R}$ is $\mathrm{G} / \mathrm{A}, \mathrm{Y}$ is $\mathrm{T} / \mathrm{C}, \mathrm{V}$ is $\mathrm{A} / \mathrm{C} / \mathrm{G}$ and $\mathrm{M}$ is $\mathrm{A} / \mathrm{C}$. The amplification was initiated with a 5 min denaturation at $94{ }^{\circ} \mathrm{C}$, followed by 35 cycles of denaturation at $94{ }^{\circ} \mathrm{C}$ for $1 \mathrm{~min}$; annealing at $56^{\circ} \mathrm{C}$ for $1 \mathrm{~min}$; and primer extension at $72{ }^{\circ} \mathrm{C}$ for $3 \mathrm{~min}$; the final elongation step was $7 \mathrm{~min}$ at $72^{\circ} \mathrm{C}$. The amplified products were analysed by agarose gel electrophoresis, isolated by adsorption to glass silica beads (GeneClean II; Bio101), digested and cloned into the HindIII/XbaIdigested pUC18 vector. The cloned PCR fragment was sequenced and then used as a probe to screen a genomic library.

\section{RESULTS}

\section{Detection of a secreted acid protease activity}

Mycelium from Scl. sclerotiorum, grown for $48 \mathrm{~h}$ in a minimal medium containing glucose and $\mathrm{NH}_{4} \mathrm{Cl}$, was harvested by filtration, washed in sterile water then transferred to minimal medium supplemented with sunflower extracts used as the sole carbon and nitrogen sources. Eight hours after transfer, the cell-free culture medium was collected and assayed for protease activity. At this time, this enzymic activity was maximal and remained stable for several hours. The $\mathrm{pH}$ optimum of the protease activity was determined. The highest level of activity was detected at $\mathrm{pH} 4 \cdot 5$ and a minor peak was repeatedly found at $\mathrm{pH} 2$. At least two families of proteases are therefore likely to contribute to the total proteolytic activity measured under these culture conditions. Pepstatin, a specific inhibitor of aspartyl proteases, was tested in order to identify the type of proteases responsible for this acidic enzymic activity. The activity at $\mathrm{pH} 4.5$ was strongly inhibited $(75 \%)$ by pepstatin, while the activity at $\mathrm{pH} 2$ was only weakly inhibited $(15 \%)$. These data indicate that the main protease activity secreted into the medium corresponds to an aspartyl protease. On the other hand, the enzyme responsible for the activity at $\mathrm{pH} 2$ seems to belong to another class of acid protease. PMSF, E-64 and phosphoramidon, inhibitors of serine, cysteine and metalloproteases, respectively, did not affect this latter activity, indicating that the acidic activity secreted in the medium containing cell walls consists of overlapping activities of aspartyl and non-aspartyl proteases (G. Billon-Grand, N. Poussereau \& M. Fèvre, unpublished). The acidic pepstatin-non-inhibitable enzymic activity exhibits properties similar to those of the non-aspartyl acid proteases from Aspergillus niger (Iio \& Yamasaki, 1976), Scytalidium lignicolum (Maïta et al., 1984) and Cryphonectria parasitica (Jara et al., 1996). It was therefore of interest to isolate and characterize the gene encoding this enzymic activity to understand the regulation of its expression during pathogenesis.

\section{Isolation and characterization of acp1}

Acid proteases have been isolated and characterized for only three filamentous fungi: A. niger (Takahashi et al., 1991), Scy. lignicolum (Maïta et al., 1984) and C. parasitica (Jara et al., 1996). Comparison of the amino acid sequences of these proteases revealed several conserved regions which could be used for designing primers for PCR amplification. Oligonucleotides corresponding to the conserved regions WYEWY and NAEWI allowed amplification of a single fragment of $204 \mathrm{bp}$ from Scl. sclerotiorum genomic DNA. Its identity was confirmed by sequencing and by comparison with the sequences of known acid proteases.

The PCR fragment, cloned in pUC18, was used as a probe to screen a genomic library of Scl. sclerotiorum constructed in the lambda phage EMBL3 (Riou, 1991). Four hybridizing clones were selected out of $10^{4}$ individual recombinant bacteriophage plaques. The phages were isolated, purified, and their DNA digested with several restriction enzymes and subjected to Southern analysis. A DNA fragment of $1.3 \mathrm{~kb}$, present in all the phages hybridizing to the probe, was cloned into the PstI site of pBluescript, yielding the plasmid pAC1.

Southern blot analysis of genomic DNA of Scl. sclerotiorum was performed using the $204 \mathrm{bp}$ PCR fragment described above as a probe. Genomic DNA was digested with different restriction enzymes for which no internal site was present in the amplified fragment, transferred to a Nylon membrane and hybridized under low stringency. Southern analysis showed that the PCR fragment hybridized to a single band (data not shown), indicating that the acid protease activity is encoded by a single 


\begin{tabular}{|c|c|c|}
\hline ACP1 & MKFS--IVAATALLAGSAVAAP-----GTALRQARAVKRAA---RTHGNPVK-YVEG--- & \\
\hline PRTA & MKFS--TILTGSLFATAALAAAP-----LTEKRRARKEARAAG--KRHSNPP--YIPGSDK & \\
\hline EAPC & MKYA--TVVAALLGANAALGAR-----FTEKRRERNEARL_ARRSGSVRLPAT-NSEGVAI & \\
\hline EAPB & MKYT--AAL_AALVTLAAAAPTDGIIDIGDGVKLVPREPRAHTRLERLRTFRRGLMEGLES & \\
\hline \multirow[t]{3}{*}{ SLB } & MKFTTAAVLSALVSAEIAFAAPG--GNGFARRQARRQARAAG---LKASPFR------- & \\
\hline & $* *:: \quad: \quad: \quad * \quad: \quad \quad:$ & \\
\hline & 61 & \\
\hline ACP1 & ----PTN-KTDVSYSSNWAGAVLVGTGYTSVTGTFTAPSPSTAGSGS---------- & \\
\hline PRTA & EIL-KLNGTTNEEYSSNWAGAVLIGDGYTKVTGEFTVPSVSAGSSGSSGYGGGYGYWKNK & \\
\hline EAPC & DAAESRNDTTNVEYSSNWAGAVLIGSGYKSVIGIFVVPTPKSPGSGN--------- & \\
\hline EAPB & G---ERN-SSDVSYDSNWAGAVKIGTGLNDVTGTIVVPTPSVPSGGSS---------- & \\
\hline \multirow[t]{3}{*}{ SLB } & ----QVN-AKEATVESNWGGAILIGSDFDTVSATANVPSATGASGGS------------ & \\
\hline & ${ }^{*} \quad . \quad .^{* * *} \cdot *^{*}::^{*} \cdot{ }^{*}: . \quad .^{*}: \cdot .^{*}$ & \\
\hline & 121 & \\
\hline ACP1 & ------AWVGIDGDTCGTAILQTGIDWDKSGNSITYDAWYEWYPDYAYDFSGISISA & \\
\hline PRTA & EQSEEYCASAWVGIDGDTCETAILQTGVDFCYEDGQTSYDAWYEWYPDYAYDFSDITISE & \\
\hline EAPC & ---TEYAASAWVGIDGDTAQNSILQTGVDFYVEGSSVAYDAWYEWYPDYAYDFSGISISA & \\
\hline EAPB & --TAKYAASAWVGIDGDTCTSAILQTGVDFYAGRGGVSFDAWYEWYPNYAYDFSGFSVSA & \\
\hline \multirow[t]{3}{*}{ SLB } & ------SAAWVGIDGDTCQTAILQTGFDWYGDG---TYDAWYEWYPEVSDDFSGITISE & \\
\hline & 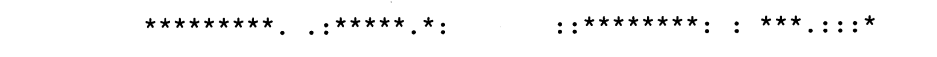 & \\
\hline & 181 & \\
\hline ACP1 & GDSIKVTVTASSKTTGTATVDNLTKGKSVTHTFSGGVDGDLCEYNAEWIVEDFEE----G & \\
\hline PRTA & GDSIKVTVEATSKSSGSATVENLTTGQSVTHTFFSGNVEGDLCETNAEWIVEDFES----G & \\
\hline EAPC & GDTIKVTVTATTTTSGTAVVENVTKGTTVTHTFTG-QSAALQELNAEWIVEDFEE----G & Fig. 1. Comparison of the predicted amino \\
\hline EAPB & GDTIVMTASASSLKAGTVTLENSTTGKKVTQSFSA-ESSELCEYNAEWIVEDFES----G & acid sequence of ACP1 of Scl. sclerotiorum \\
\hline SLB & 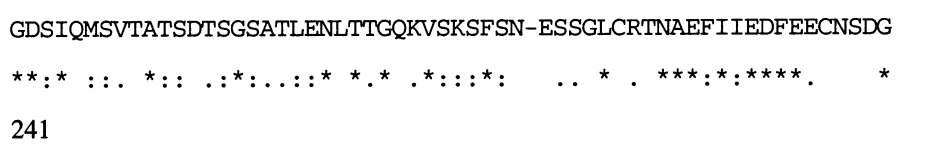 & $\begin{array}{l}\text { with the corresponding sequences of the } \\
\text { fungal acid proteases PRTA from } A \text {. niger, } \\
\text { SLB from Scy. lignicolum, EAPB and EAPC } \\
\text { from C. parasitica. Amino acids that are } \\
\text { conserved in all proteins are marked }\end{array}$ \\
\hline ACP1 & -SSLVQFANFG-TVTFTGASATQNGESVGVTGAQIIDLQQN-SVLTSVSTSSNS-VTVKYV- & $\begin{array}{l}\text { by asterisks; dots indicate conservative } \\
\text { replacements. Dashes indicate gaps intro- }\end{array}$ \\
\hline PRTA & -DSLVAFADFG-SVTFTNAEATSGGSTVGPSDATVMDIEQDGSVLTETSVSGDS-VTVTYV- & duced by the CLUSTAL program to optimize \\
\hline EAPC & -DELVPFANFG-TVTFTGAEATTSSGTVTAADATLIDIEQNGEVLTSVTVSGST-VTVKYV- & $\begin{array}{l}\text { the sequence alignments. The } \mathrm{N} \text {-terminal } \\
\text { residue of mature PRTA, EAPC and SLB is }\end{array}$ \\
\hline EAPB & -SSLVNFADFD-TVTFKDCSPSVSG-------STIVDIRQSLEVLTECSTTGTTTVTCEYVG & underlined. The putative $\mathrm{N}$-terminal residue \\
\hline SLB & 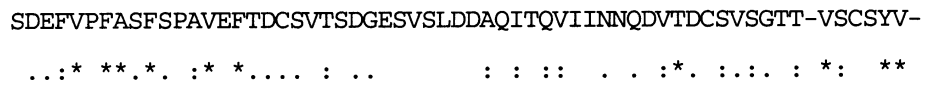 & $\begin{array}{l}\text { intervening sequence separating the two } \\
\text { chains of PRTA is boxed. }\end{array}$ \\
\hline
\end{tabular}

gene, as described for A. niger and Scy. lignicolum (Takahashi et al., 1991; Oda et al., 1998).

The nucleotide sequence of the cloned fragment determined by sequencing both strands revealed that it contains the entire nucleotide sequence of the acp 1 gene (GenBank accession no. AF221843). The acp1 gene consists of an intronless ORF of 759 bases, which encodes a polypeptide of $252 \mathrm{aa}$. By comparison with the $\mathrm{N}$-terminal region of secreted acid proteases of $C$. parasitica (Jara et al., 1996) and A. niger (Takahashi et al., 1991), it may be assumed that acp1 is synthesized as a zymogen following the general rule for fungal acid proteases (aspartyl or non-aspartyl proteases) and con- tains an $\mathrm{N}$-terminal preproregion of 52 aa (Fig. 1). The mature form of the enzyme would be a 200 residue protein with a calculated molecular mass of $20.7 \mathrm{kDa}$ and a calculated $\mathrm{pI}$ of $3 \cdot 9$. The deduced primary sequence of the mature protease contains one potential $\mathrm{N}$-linked glycosylation site.

The mature ACP1 protein exhibits $62 \%$ identity with protease A (PRTA) of A. niger (Takahashi et al., 1991), $65 \%$ and $55 \%$ identity with EAPC and EAPB of C. parasitica (Jara et al., 1996), respectively, and 50\% identity with SLB of Scy. lignicolum (Maïta et al., 1984). In A. niger, the enzyme has a two-chain structure with a light chain non-covalently linked to the heavy chain 

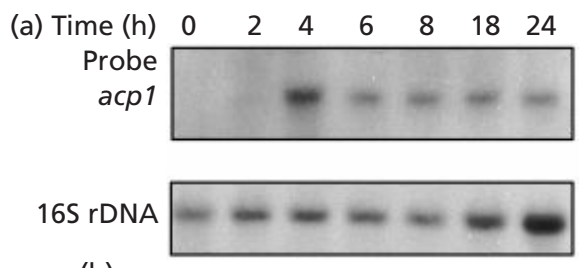

(b)

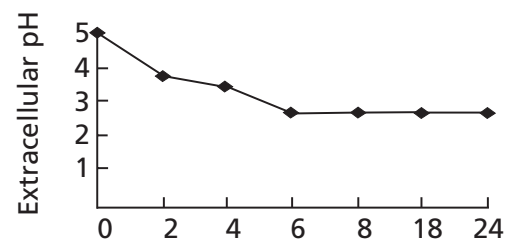

(c)

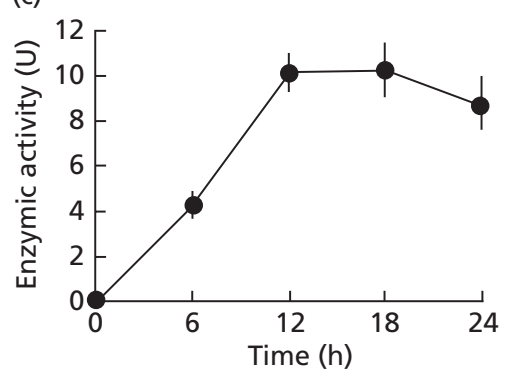

Fig. 2. Expression of acp1 of Scl. sclerotiorum grown in the presence of sunflower extracts. Mycelia were grown for $48 \mathrm{~h}$ in a glucose- $\mathrm{NH}_{4}$ medium (lane 1) then transferred to a medium containing sunflower extracts. At different times after transfer, total RNA was extracted, electrophoresed on agarose gels and hybridized with acp1 (a). As a control for RNA loading, filters were stripped and re-probed with the rDNA probe. The $\mathrm{pH}$ of the culture medium was measured (b) and the secreted acid protease activity was assayed (c). The results of one representative experiment are presented. Protease activity was assayed in triplicate; values shown represent the mean and bars show standard deviation.

(Inoue et al., 1991; Takahashi et al., 1991). In the deduced amino acid sequence of the precursor of that protein, the two chains are separated by an intervening sequence of 11 residues. Interestingly, this intervening sequence appears to be specific to the $A$. niger enzyme and is not found in the deduced polypeptide sequences of the other genes encoding acid proteases (Fig. 1). By comparison with the enzymes from Scy. lignicolum and C. parasitica, the acid protease from Scl. sclerotiorum appears to be a single-chain enzyme.

\section{acp1 expression during saprophytic growth of Scl. sclerotiorum}

Transfer experiments were performed to investigate acp1 expression during growth in the presence of plant extracts. Scl. sclerotiorum was grown for $48 \mathrm{~h}$ in a medium containing glucose and $\mathrm{NH}_{4}$ then collected, washed with distilled water and transferred to a minimal medium containing sunflower extracts. Total RNA isolated at different times after transfer was hybridized with acp1 then with $16 \mathrm{~S}$ rDNA (Fig. 2). No acp1 signal was detected at the time of transfer to minimal medium,

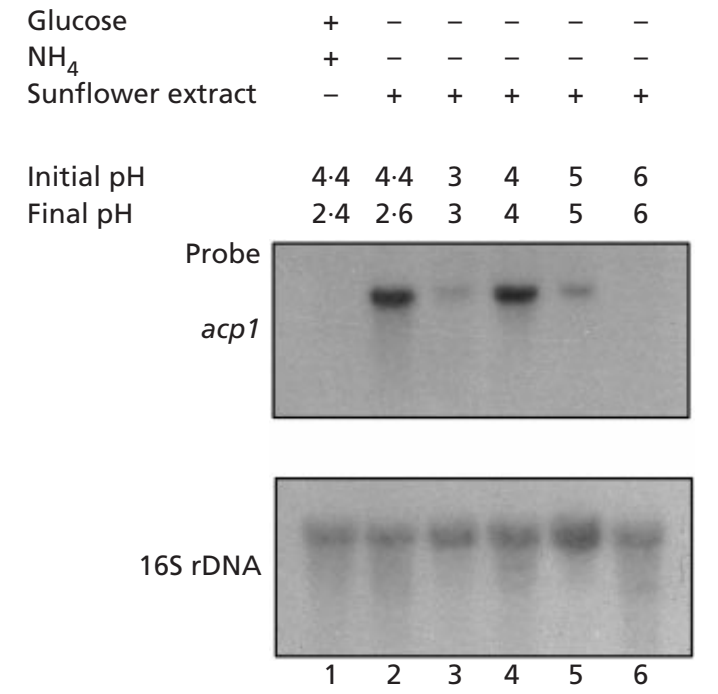

Fig. 3. Effect of $\mathrm{pH}$ on regulation of acp1 expression. Mycelia were grown for $48 \mathrm{~h}$ in a glucose- $\mathrm{NH}_{4}$ medium (lane 1) then transferred to a medium containing sunflower extracts, nonbuffered (lane 2) or buffered at different pH values (lanes 3-6). Eight hours after transfer, the $\mathrm{pH}$ of the culture medium was measured and total RNA extracted, electrophoresed on agarose gels and hybridized with acp1. As a control for RNA loading, filters were stripped and re-probed with the rDNA probe.

indicating that the protease gene is not constitutively expressed. Four hours after transfer, a strong signal was observed and $8 \mathrm{~h}$ after transfer the hybridization signal decreased and then appeared to remain at a constant level. On the other hand, the enzymic activity measured in the culture medium, which seems likely to be attributable to the acp1 gene product, continued to increase up to $8 \mathrm{~h}$ after transfer then remained high. $\mathrm{Scl}$. sclerotiorum secretes oxalic acid during growth (Magro et al., 1984). Consequently, the $\mathrm{pH}$ of the culture medium decreased rapidly and $6 \mathrm{~h}$ after transfer stabilized to $\mathrm{pH} 2 \cdot 5-3$ (Fig. 2). Constant levels of $\mathrm{pH}$ and of acp1 transcripts were observed at the same time following transfer, suggesting that the ambient $\mathrm{pH}$ may affect acp1 expression.

\section{acp1 expression is $\mathrm{pH}$ regulated}

The effect of the ambient $\mathrm{pH}$ of the medium was studied by transferring mycelia cultivated for $48 \mathrm{~h}$ in a minimal medium supplemented with glucose and $\mathrm{NH}_{4}$ to unbuffered or buffered media at $\mathrm{pH} 3,4,5$ and 6 containing sunflower extracts as the carbon and nitrogen sources. Eight hours after transfer, total RNA was extracted for Northern analysis and blots were incubated with the acp 1 and rDNA probes. The data presented in Fig. 3 show that acp1 expression is strictly dependent on the ambient $\mathrm{pH}$. Expression was restricted to a very narrow range of $\mathrm{pH}$, being maximal at $\mathrm{pH} 4$, weakly expressed at $\mathrm{pH} 3$ and 5, and not detected at $\mathrm{pH}$ 6. In the unbuffered medium, the $\mathrm{pH}$ progressively decreased from $4 \cdot 4$ to $2 \cdot 6$, allowing the strong expression of acp1 


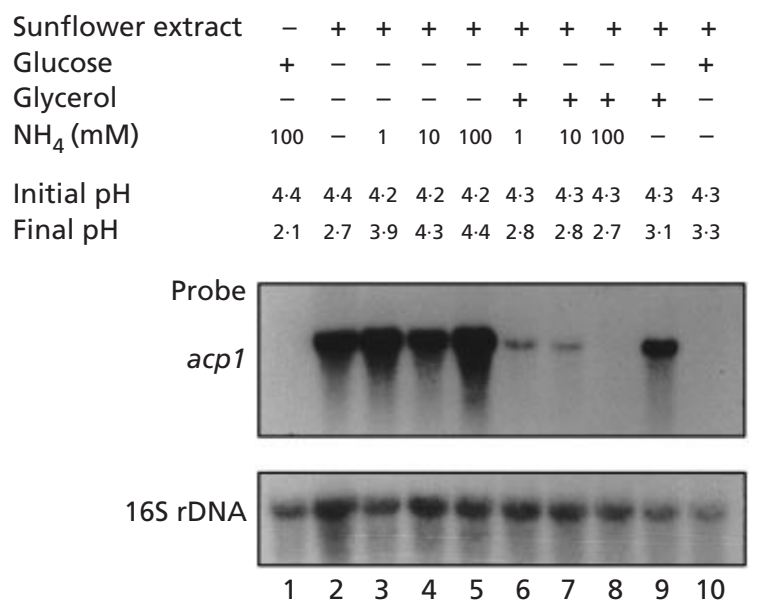

Fig. 4. Effects of carbon and nitrogen sources on acp1 expression. Mycelia were grown for $48 \mathrm{~h}$ in a glucose- $\mathrm{NH}_{4}$ medium (lane 1) then transferred to a medium containing sunflower extracts (lane 2) supplemented with ammonium (lanes 3-5), ammonium and 2\%, v/v, glycerol (lanes 6-8), 2\%, v/v, glycerol (lane 9) or $2 \%$ glucose (lane 10). Eight hours after transfer, the $\mathrm{pH}$ of the culture medium was measured. Total RNA was extracted, electrophoresed on agarose gels and hybridized with acp1. As a control for RNA loading, filters were stripped and re-probed with the rDNA probe.

during this decrease. These data show that $\mathrm{pH}$ regulation overrides induction by the plant extracts and that an acidic $\mathrm{pH}$ is not sufficient to allow acp1 induction as no transcripts were detected in the glucose- $\mathrm{NH}_{4}$ medium.

\section{Carbon and nitrogen regulation of acp 1}

The effect of carbon and nitrogen sources on acp1 expression was examined by Northern analysis (Fig. 4). Mycelia were grown for $48 \mathrm{~h}$ in a glucose- $\mathrm{NH}_{4}$ medium then collected, washed with distilled water and transferred to a culture medium containing sunflower extracts and/or glucose, glycerol, $\mathrm{NH}_{4}$ as easily metabolizable carbon or nitrogen sources. As previously shown, acp1 was strongly expressed in the sunflower extract medium $8 \mathrm{~h}$ after transfer (Fig. 4, lane 2). When glucose was added to that inducing medium, acp1 expression was completely abolished (Fig. 4, lane 10). In contrast, acp1 was still strongly expressed when glycerol, considered a neutral carbon source, was added to the medium instead of glucose (Fig. 4, lane 9). acp1 expression therefore seems to be controlled by glucose catabolite repression.

When increasing concentrations of $\mathrm{NH}_{4}$ (from 1 to $100 \mathrm{mM}$ ) were added to the sunflower extract medium, acp1 expression induced by the plant extracts was not repressed by the nitrogen source (Fig. 4, lanes 3, 4 and 5). However, expression of acp 1 was strongly repressed by the simultaneous presence of ammonium and glycerol (Fig. 4, lane 6, 7 and 8). Proteases release compounds which can be used as carbon sources. When a compound such as glycerol, which can fulfil the requirement for a
-926 TTATGTCTAATAGACTATACATAGACAATCCTTCATGTAAACGATGTCAC

-876 CCATCGATCGATATGTATCCAAAACCAGCAATTGGATCCTGGCATACTCC

-826 GTGCACCCACAGAATGCGACGTCTGGGGTCAAACTTCCCTGTAAGGACCT

-776 TTCTTGCATAATATACCTTCCATATTTTGCAAGAACGCAATTGCTTTTTC

-726 TTACTATGTAATGCACGATACATGCAACCATTGGCCAATATGTGGCTCAA

-676 GCGGGTATTACAAATGGATATAAGAGTTACACATATGATTTGAGATAAGC

-626 TTCTTTCATCCCCACACCACATGACTACTTTTATTGGTGGATCATTTGAG

-576 ACAGCCGCTGAAGTCCCGTTCTGTCCCTGTGCCCGTTAAATGTACATGTA

-526 CATAGGCGCCAAAACAGGGATTTTCAGATAAGAAATCAGAGGACCTCCTT

-476 TTTATGGCAATAGTTGAAGATTATCATCGAAGATCTTCAGTCAAGATGAA

-426 TGATGTTCAACAGGCGTGCTGGTTAATGAGGAAGGTGATCAAGTTGATCC

-376 ATATGGGTATTGCCCTGCCCTGCAGGCCAGCGCTAGATGTCGGCATCCAC

-326 AGTTGAATTGCCCTCAATCAAAATTTTAGACTCCTCATGCAAGTGCCGGT

-276 GAAGAAGTCCAAATCGAGCTGTCTCCATCCCATGTTGTCGTGATAACAGC

-226 ACTTTTTGATCATTCAGGAAGGTAGGTTGAGATATAGATTGAATTGCGAA

-176 TGAGTTATACGTGAAGACGAAATAGCTCACAAAGGGTATATATATCTTGT

-126 CTTCATCCGCAGGATAATATCTTTTCTCTCCAGTCCAGCATCAATCGTTT

-76 CACAGTCCTCACAGCCAATCCAATCCAATCAATCTATCAATTGTTCGTTA

-26 TTTCGACAATCAATCCATCAATCAAA ATG

Met

Fig. 5. Sequence of the acp 1 promoter region. Nucleotide numbering begins at the putative translational start of acp 1 . Putative functional AreA binding sites (GATA) are underlined. The putative PacC recognition sequence (GCCARG) is boxed and CREA (SYGGRG) binding sites are double underlined ( $R, A$ or $G$; $S, G$ or $C ; Y, C$ or T).

carbon source, is provided, nitrogen repression of protease expression can occur. This pattern of transcriptional regulation is observed for the genes involved in the utilization of metabolites such as proline or aminobutyric acid which can serve as both carbon and nitrogen sources (Arst \& Bailey, 1977; Marzluf, 1997).

\section{Analysis of the acp1 promoter sequence}

The experiments described above show that acp1 expression is controlled in a complex manner by several environmental factors. It was of interest to examine the $5^{\prime}$ non-coding sequence for the presence of motifs involved in the regulation of fungal gene expression (Fig. 5). The sequence contains 19 copies, in each orientation, of the GATA motif which is the recognition sequence of the nitrogen regulatory proteins AreA from A. nidulans (Kulmburg et al., 1993) and NIT2 from Neurospora crassa (Fu \& Marzluf, 1990). However, only eight of these motifs at the positions -912 and $-903,-867$ and $-858,-522$ and $-498,-131$ and -111 are in an inverted-repeat orientation separated by less than $30 \mathrm{bp}$, corresponding to the functional organization of the GATA binding sequences in N. crassa (De Bernardis et al., 1998; Marzluf, 1997; Caddick et al., 1994). There are three degenerate copies of the recognition sequence 5'-SYGGRG-3' of CREA, a factor involved in glucosemediated carbon catabolite repression (Kulmburg et al., 1993). Only one copy of the motif 5'-GCCARG-3', the recognition site for the PACC protein mediating $\mathrm{pH}$ regulation in A. nidulans (Tilburn et al., 1995), is present. The presence of these motifs, together with the data obtained from Northern blot analyses, suggest 

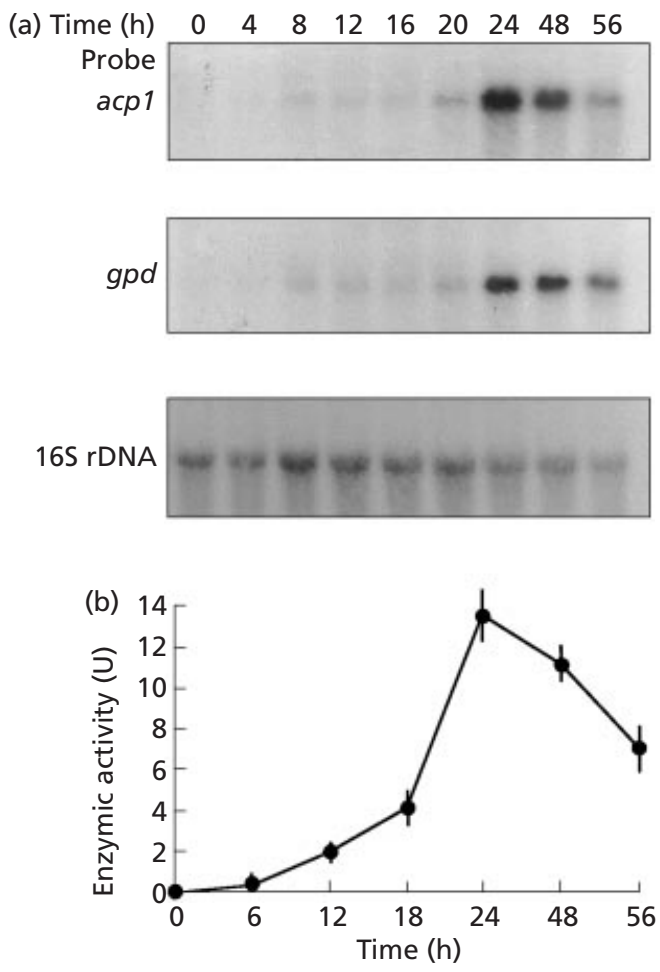

Fig. 6. Expression of acp 1 of Scl. sclerotiorum during infection of sunflower cotyledons. Mycelial disks were deposited on the upper face of the cotyledonary leaves of 1-week-old germlings. Cotyledons were collected at different times after inoculation. Total RNA was extracted, electrophoresed on agarose gels and Northern blots hybridized with acp1 (a). As controls for fungal RNA and total RNA loading, filters were stripped and then successively probed with gpd and rDNA probes, respectively. Proteins were extracted and assayed for acid protease activity (b). Protease activity was assayed in triplicate; values shown represent the mean and bars show standard deviation.

that acp1 is under the control of homologous widedomain regulatory genes in Scl. sclerotiorum.

\section{Expression of acp 1 during sunflower infection}

In planta expression of the acp1 gene of Scl. sclerotiorum was analysed in a time-course experiment. Sunflower cotyledons were infected with mycelial disks and harvested at different times after inoculation. Total RNA was extracted from healthy and infected cotyledons, and analysed using Northern blots incubated successively with acp1, gpd and $16 \mathrm{~S}$ rDNA probes (Fig. 6). To appreciate the proportion of the fungal RNA extracted from infected cotyledons, the phosphoglyceraldehyde dehydrogenase gene of Scl. sclerotiorum, $g p d$, was used as a reference; gpd is constitutively expressed during mycelial growth (P. Cotton, personal communication). Hybridization with a $16 \mathrm{~S}$ rDNA probe which reacts with fungal and plant RNA allowed an estimate of the total RNA (plant and fungal) loaded in each lane.

No hydridization signal was detected when the acp1 probe was incubated with total RNA extracted from cotyledons inoculated with heated mycelial disks, indicating that cotyledons do not express an acp1-related gene (not shown). During the early stages of the infection following inoculation with non-heated mycelial disks, a low hybridization signal with the acp1 probe was detected (Fig. 6). The level of acp1 transcripts remained low and constant during the first $16 \mathrm{~h}$ and then increased rapidly between 20 and $24 \mathrm{~h}$ of infection. This increase of the hybridization signal coincided with the phase of symptom development in which intensive colonization of the cotyledonary leaves by the fungus and maceration of host tissue occurred; at that stage, a third of the cotyledon was infected by the fungus (results not shown). This strong hybridization signal remained stable for $24 \mathrm{~h}$ and decreased $56 \mathrm{~h}$ after infection when sunflower cotyledons were completely invaded and degraded. While equal amounts of RNA were loaded, as illustrated by the rDNA hybridization, gpd hybridization was not detected in the RNA sample of noninfected cotyledons, proving the fungal specificity of the probe. Expression of $g p d$ was low at the beginning of infection, increased $24 \mathrm{~h}$ after infection and remained high during cotyledon colonization. This indicates that the amount of fungal RNA present in the total RNA extracted from infected plant tissues increased suddenly at the start of leaf necrosis. The enzymic activity likely to have been attributable to ACP1, detected during the early stages of infection, increased to reach a maximal level $24 \mathrm{~h}$ after infection then decreased during spreading of the cotyledon necrosis. This enzymic activity appeared therefore to be transient.

\section{DISCUSSION}

When grown in vitro in the presence of a crude sunflower extract, or during plant infection, Scl. sclerotiorum secretes a pool of acidic proteases which contains at least two types of enzymes: the aspartyl protease and the non-aspartyl protease. The first enzymic activity is characterized by an optimal $\mathrm{pH}$ of 4.5 and is sensitive to pepstatin, a specific aspartyl protease inhibitor. The latter enzymic activity is defined by a $\mathrm{pH}$ optimum of $\mathrm{pH} 2$ and is not inhibited markedly by pepstatin; such properties are similar to those of PRTA of A. niger (Iio \& Yamasaki, 1976), SLB of Scy. lignicolum (Maïta et al., 1984) and EAPB and EAPC of C. parasitica (Jara et al., 1996). We have cloned the acp1 gene encoding a nonaspartyl acid protease of $\mathrm{Scl}$. sclerotiorum and investigated its pattern of expression. Previous studies have shown that expression of aspartyl- and metallo-proteases is regulated in response to environmental signals (Jarai \& Buxton, 1994; Hensel et al., 1995; Gente et al., 1997; St Leger et al., 1997). It was of interest to determine the factors which influence, in vitro, the expression of the acp1 gene to relate these to the environmental conditions encountered in planta by the fungus during symptom development. In this study, we show that acp 1 expression is tightly regulated at the level of transcription by the availability of carbon and nitrogen sources, and by the ambient $\mathrm{pH}$. 
acp1 expression was induced when the mycelium was cultivated in the presence of sunflower extracts. The presence of glucose prevented this induction, indicating that production of this protease is regulated by carbon catabolite repression. These data are compatible with the presence, in the $S \mathrm{Scl}$. sclerotiorum acp1 promoter, of several binding sites for the glucose repressor CREA, and with the synthesis and nuclear compartmentation of the homologous protein CRE1 in the presence of glucose (Vautard-Mey et al., 1999). The addition of ammonium to the plant-cell-extract medium did not repress acp1 expression, indicating that this preferred nitrogen source is, on its own, unable to induce nitrogen repression. However the addition of glycerol, a non-repressive carbon source on its own, to media which contained plant-cell extracts and an increasing concentration of ammonium, reduced markedly acp1 expression leading to full repression at an ammonium concentration of $100 \mathrm{mM}$. This control, induced by the simultaneous presence of carbon and nitrogen sources, indicates that the sunflower cell-wall preparation did not contain available single carbon sources, as acp 1 was expressed in the presence of ammonium and the cell-wall preparation. The products released by cell-wall-protein proteolysis must serve as both carbon and nitrogen sources with nitrogen repression by a convenient nitrogen source (i.e. $\mathrm{NH}_{4}$ ) only occurring when the requirement for a carbon source is fulfilled i.e. by the addition of glycerol. This situation is reminiscent of the situation for a set of proline-specific genes in $A$. nidulans: repression of these genes requires the presence of both ammonium and glucose (Gonzalez et al., 1997). Inducer exclusion appears to be responsible for the carbon and nitrogen repression of the genes of the proline utilization gene cluster of A. nidulans (Marzluf, 1997; Cubero et al., 2000). It will be of interest to determine whether protease inducers are released in the presence of nitrogen and carbon sources in Scl. sclerotiorum; their absence would signify that nitrogen and carbon metabolite repression of acp1 expression is indirect by prevention of inducer production or by inducer exclusion.

Expression of acp1 is also tightly regulated by ambient $\mathrm{pH}$. Following transfer of mycelium into inducing medium, acp1 transcripts were only detected within a very narrow range of ambient $\mathrm{pH}$, between $\mathrm{pH} 3$ and 5 . Transcription of acp1 requires acidic environmental conditions; the presence of a proteinaceous inducer is not sufficient for expression of this gene. $\mathrm{pH}$ control overrides induction. Moreover, synthesis of the acidic ACP1 is prevented at neutral or alkaline $\mathrm{pH}$ values at which the enzyme is inactive. $\mathrm{pH}$ regulation is an adaptive response for the production of secreted enzymes at their optimal pH of activity (Jarai \& Buxton, 1994; Gente et al., 1997). In A. nidulans, the PacC transcription factor has been shown to activate transcription of alkaline genes and to repress transcription of acidic genes (Tilburn et al., 1995). Identification of a pacC homologue in Scl. sclerotiorum (S. Creton \& N. Poussereau, unpublished data) together with the pres- ence of a PacC binding site in the promoter region of acp1 (Fig. 5), suggest the involvement of a $\mathrm{pH}$ regulator in the control of acp1.

We have investigated the pattern of acp 1 expression in response to changes in the availability of carbon and/or nitrogen sources, and alteration of the ambient $\mathrm{pH}$ demonstrating that $\mathrm{pH}$ controls the circuit of acp1 induction and repression prevails over specific induction. acp1 is strongly expressed in planta during the course of symptom development of infected sunflower cotyledons. The ambient conditions which impose a very tight control of acp1 expression in vitro must be encountered in planta to allow acp1 expression during infection. The $\mathrm{pH}$-conditional expression observed in vitro suggests that $\mathrm{pH}$ during infection must rapidly become acidic to reach $\mathrm{pH} 4$, the value allowing acp1 expression. In vitro, glucose imposes full repression but carbon catabolite repression must not occur during infection as acp1 is expressed at the early stages of infection. Similarly, nitrogen limitation may also allow gene expression during infection as illustrated in other systems (Talbot et al., 1997; Coleman et al., 1997).

In summary, using acp1 as a reporter system and by comparing in vitro and in planta gene expression it was possible to define conditions which mirror growth conditions in plant tissues. Our data suggest that glucose and nitrogen starvation together with acidification are key factors which control Scl. sclerotiorum gene expression during pathogenesis.

\section{ACKNOWLEDGEMENTS}

This work was supported by grants from the CNRS and the Université Claude Bernard Lyon1.

\section{REFERENCES}

Alghisi, P. \& Favaron, F. (1995). Pectin-degrading enzymes and plant-parasite interactions. Eur J Plant Pathol 101, 365-375.

Annis, S. L. \& Goodwin, P. H. (1997). Recent advances in the molecular genetics of plant cell wall-degrading enzymes produced by plant pathogenic fungi. Eur J Plant Pathol 103, 1-14.

Arst, H. N, Jr \& Bailey, C. R. (1977). The regulation of carbon metabolism. In Genetics and Physiology of Aspergillus, pp. 131-145. Edited by J. E. Smith \& J. A. Pateman. London: Academic Press.

Ball, A. M., Ashby, A. M., Daniels, M. J., Ingram, D. S. \& Johnstone, K. (1991). Evidence for the requirement of extracellular protease in the pathogenic interaction of Pyrenopeziza brassicae with oilseed rape. Physiol Mol Plant Pathol 38, 147-161.

Bidochka, M. J., Burke, S. \& Ng, L. (1999a). Extracellular hydrolytic enzymes in the fungal genus Verticillium: adaptations for pathogenesis. Can J Microbiol 45, 856-864.

Bidochka, M. J., St Leger, R. J., Stuart, A. \& Gowanlock, K. (1999b). Nuclear rDNA phylogeny in the fungal genus Verticillium and its relationship to insect and plant virulence, extracellular proteases and carbohydrases. Microbiology 145, 955-963.

Bradford, M. M. (1976). A rapid and a sensitive method for the quantitation of microgram quantities of protein utilizing the principle of protein-dye binding. Anal Biochem 72, 248-264. 
Brownlee, A. G. (1988). A rapid DNA isolation procedure applicable to many refractory filamentous fungi. Fungal Genet Newsl 35, 8-9.

Caddick, M., Brownlee, A. \& Arst, H. (1986). Regulation of gene expression by $\mathrm{pH}$ of the growth medium in Aspergillus nidulans. Mol Gen Genet 203, 346-353.

Carpita, N. C. \& Gibeaut, D. M. (1993). Structural models of primary cell walls in flowering plants: consistency of molecular structure with the physical properties of the walls during growth. Plant J 3, 1-30.

Chen, Z. B., Lax, A., Cleverland, T. \& Russin, J. (1999). Inhibition of plant pathogenic fungi by a corn trypsin inhibitor overexpressed in Escherichia coli. Appl Environ Microbiol 65, 1320-1324.

Coleman, M., Henricot, B., Arnau, J. \& Oliver, R. P. (1997). Starvation-induced genes of the tomato pathogen Cladosporium fulvum are also induced during growth in planta. Mol PlantMicrobe Interact 10, 1106-1109.

Cubero, B., Gomez, D. \& Scazzochio, C. (2000). Metabolite repression and inducer exclusion in the proline utilization gene cluster of Aspergillus nidulans. J Bacteriol 182, 233-235.

De Bernardis, F., Mühlschlegel, F. A., Cassone, A. \& Fonzi, W. A. (1998). The $\mathrm{pH}$ of the host niche controls gene expression in and virulence of Candida albicans. Infect Immun 66, 3317-3325.

Fraissinet-Tachet, L., Reymond-Cotton, P. \& Fevre, M. (1995). Characterization of a multigene family encoding an endopolygalacturonase in Sclerotinia sclerotiorum. Curr Genet 29, 96-99.

Fu, Y. H. \& Marzluf, G. A. (1990). nit-2, the major positive acting nitrogen regulatory gene of Neurospora crassa, encodes a sequence specific DNA-binding protein. Proc Natl Acad Sci U S A 87, 5331-5335.

Gente, S., Durand-Poussereau, N. \& Fevre, M. (1997). Controls of the expression of aspA, the aspartyl protease gene of Penicillium roqueforti. Mol Gen Genet 256, 557-565.

Gonzalez, R., Gavrias, V., Gomez, D., Scazzocchio, C. \& Cubero, B. (1997). The integration of nitrogen and carbon catabolite repression in Aspergillus nidulans requires the GATA factor AreA and an additional positive-acting element, ADA. EMBO J 16, 2937-2944.

Griffen, A. M., Wiebe, M. G., Robson, G. D. \& Trinci, A. P. J. (1997). Extracellular proteases produced by the Quorn mycoprotein fungus Fusarium graminearum in batch and chemostat culture. Microbiology 143, 3007-3013.

Hensel, M., Tang, C. M., Arst, H. N., Jr \& Holden, D. W. (1995). Regulation of fungal extracellular proteases and their role in mammalian pathogenesis. Can J Bot 73, S1065-S1070.

lio, K. \& Yamasaki, M. (1976). Specificity of acid protease A from Aspergillus niger var. macrosporus towards B-chain of performic acid oxidized bovine insulin. Biochim Biophys Acta 429, 912-924.

Inoue, H., Kimura, T., Makabe, O. \& Takahashi, K. (1991). The gene and deduced protein sequences of the zymogen of Aspergillus niger acid protease A. J Biol Chem 226, 19484-19489.

Jara, P., Gilbert, S., Delmas, P., Guillemot, J. C., Jaghad, M., Ferrara, P. \& Loison, G. (1996). Cloning and characterization of the eapB and eapC genes of Cryphonectria parasitica encoding two new acid proteinases, and disruption of eapC. Mol Gen Genet 250, 97-105.

Jarai, P. \& Buxton, F. (1994). Nitrogen, carbon and $\mathrm{pH}$ regulation of extracellular acidic proteases of Aspergillus niger. Curr Genet 26, 238-244.

Kulmburg, P., Mathieu, M., Dowzer, C., Kelly, J. \& Felenbok, B. (1993). Specific binding sites in the alcR and alcA promoters of the ethanol regulon for the CREA repressor mediating carbon catabolite repression in Aspergillus nidulans. Mol Microbiol 7, 847-857.

Magro, P., Marciano, P. \& Di Lenna, P. (1984). Oxalic acid production and its role in pathogenesis of Sclerotinia sclerotiorum. FEMS Microbiol Lett 24, 9-12.

Maïta, T., Nagata, S., Matsuda, G., Maruta, S., Oda, K., Murado, S. \& Tsuru, D. (1984). Complete amino acid sequence of Scytalidium lignicolum acid protease B. J Biochem 95, 465-475.

Martel, M., Letoublon, R. \& Fevre, M. (1996). Purification of endopolygalacturonase from Sclerotinia sclerotiorum: multiplicity of the complex enzyme system. Curr Genet 33, 243-248.

Marzluf, G. A. (1997). Genetic regulation of nitrogen metabolism in the fungi. Microbiol Mol Biol Rev 61, 17-32.

Movahedi, S. \& Heale, J. B. (1990). The roles of aspartic protease and endo-pectin lyase enzymes in the primary stages of infection and pathogenesis of various host tissues by different isolates of Botrytis cinerea Pers. ex Pers. Physiol Mol Plant Pathol 36, 303-324.

Murphy, J. M. \& Walton, J. D. (1996). Three extracellular proteases from Cochliobolus carbonum: cloning and targeted disruption of ALP1. Mol Plant-Microbe Interact 9, 290-297.

Oda, N., Gotoh, Y., Oyama, H., Murao, S., Oda, K. \& Tsuru, D. (1998). Nucleotide sequence of the gene encoding the precursor protein of pepstatin insensitive acid protease B, scytalidopepsin B, from Scytalidium lignicolum. Biosci Biotechnol Biochem 62, 1637-1639.

Oliver, R. \& Osbourn, A. (1995). Molecular dissection of fungal phytopathogenicity. Microbiology 141, 1-9.

Pernas, M., Lopez-Solanilla, E., Sanchez-Monge, R., Salcedo, G. \& Rodriguez-Palenzuela, P. (1999). Antifungal activity of a plant cystatin. Mol Plant-Microbe Interact 12, 624-627.

Rauscher, M., Mendgen, K. \& Deising, H. (1995). Extracellular proteases of the rust fungus Uromyces viciae-fabae. Exp Mycol 19, 26-34.

Riou, C. (1991). Production et sécretion du système hydrolytique de Sclerotinia sclerotiorum: analyses biochimiques et génétiques. PhD thesis: Université Lyon1.

Riou, C., Freyssinet, G. \& Fevre, M. (1991). Production of cell wall degrading enzymes by the phytopathogenic fungus Sclerotinia sclerotiorum. Appl Environ Microbiol 57, 1478-1484.

Ryan, C. A. (1990). Protease inhibitors in plants: genes for improving defences against insects and pathogens. Annu Rev Phytopathol 28, 425-429.

Sambrook, J., Fritsch, E. F. \& Maniatis, T. (1989). Molecular Cloning: a Laboratory Manual, 2nd edn. Cold Spring Harbor, New York: Cold Spring Harbor Laboratory.

St Leger, R. J., Joshi, L. \& Roberts, D. W. (1997). Adaptation of proteases and carbohydrases of saprophytic, phytopathogenic and entomopathogenic fungi to the requirements of their ecological niches. Microbiology 143, 1983-1992.

Takahashi, K., Inoue, H., Kohama, T. \& 8 other authors (1991). The primary structure of Aspergillus niger acid protease A. J Biol Chem 226, 19480-19483.

Talbot, N. J., McCafferty, H. R., Ma, M., Moore, K. \& Hamer, J. E. (1997). Nitrogen starvation of the rice blast fungus Magnaporthe grisea may act as an environmental cue for disease symptom expression. Physiol Mol Plant Pathol 50, 179-195.

Tilburn, J., Sarkar, S., Widdick, D. A., Espeso, E. A., Orejas, M., Mungroo, J., Penalva, M. A. \& Arst, H. N., Jr (1995). The Aspergillus PacC zinc finger transcription factor mediates regu- 
lation of both acid and alkaline expressed genes by ambient $\mathrm{pH}$. EMBO J 14, 779-790.

Vautard-Mey, G., Cotton-Reymond, P. \& Fevre, M. (1999). Expression and compartmentation of the glucose repressor CRE1 from the phytopathogenic fungus Sclerotinia sclerotiorum. Eur J Biochem 226, 252-259.
Walton, J. D. (1994). Deconstructing the cell wall. Plant Physiol 104, 1113-1118.

Received 30 May 2000; revised 2 November 2000; accepted 16 November 2000. 